\title{
EUROPA ŚRODKOWA W BADANIACH NAD SZTUKĄ: OD GEOGRAFII ARTYSTYCZNEJ DO „HORYZONTALNEJ HISTORII SZTUKI”
}

Do najżywiej dyskutowanych nurtów badawczych akademickiej historii sztuki należy w ostatnich latach geografia artystyczna ${ }^{1}$. Narodziła się ona w środku Europy około 1910 r., jednak nie od razu ważną rolę odgrywał w niej namysł nad Europą Środkową. Obszar ten, pojmowany jako odrębny region artystyczny, historycy sztuki zaczęli dostrzegać u schyłku lat sześćdziesiątych XX w., ale przełomowy okazał się dopiero czas około roku 1989. W ostatniej dekadzie badania nad swoistością regionu środkowoeuropejskiego nie tylko nie wybrzmiały w historii sztuki, lecz nawet okazały się kluczowe dla powstawania nowych koncepcji metodologicznych, z których bodaj ostatnią, sformułowaną tuż przed 2010 r., jest „, horyzontalna historia sztuki".

Oczywiście już autorzy starożytni sytuowali opisywane wydarzenia a także dzieła - nie tylko w czasie, lecz także w przestrzeni. Teoretykom architektury, poczynając od Witruwiusza, nieobce była rozważania nad znaczeniem takich czynników, jak ukształtowanie terenu, klimat lub obyczaje, czego świadectwem jest także Krótka nauka budownicza [- - ] podług nieba i zwyczaju polskiego z $1659 \mathrm{r}^{2}$ Dawni autorzy nie stosowali kategorii „krajobrazu kulturowego” czy „regionu artystycznego”, choć ich dzieła bywały pochwałą poszczególnych krain. Pierwsze wydanie Żywotów najsławniejszych malarzy, rzeźbiarzy i architektów Giorgia Vasariego (1550) jest wielką apologią

${ }^{1}$ Oprócz prac cytowanych niżej zob.: J.S. Kębłowski, Kilka uwag na temat badań tzw. geografii sztuki, w: Sztuka pograniczy Rzeczypospolitej w okresie nowożytnym od XVI do XVIII wieku, red. A. J. Baranowski, Warszawa 1998, s. 25-44.

${ }^{2}$ Krótka nauka budownicza dworów, pałaców, zamków podług nieba i zwyczaju polskiego, oprac. A. Miłobędzki, Wrocław 1957, zwł. s. XXIX-XXXIII. 
Florencji. W drugiej edycji (1568) pojawiły się sylwetki nie tylko artystów włoskich, lecz także północnych; punktem odniesienia pozostała Italia, ale zaczął się zarysowywać drugi biegun świata sztuki - Niderlandy. Brak jednak między nimi „środka”3. Nie szukali go także kontynuatorzy i naśladowcy Vasariego po północnej stronie Alp. Jeśli jednak próbować sztucznie go wyznaczyć, niewątpliwie sytuowałby się on między Italią a Niderlandami. Dopiero później obok osi Południe-Północ zarysował się także kierunek Zachód-Wschód, który z czasem miał zdominować koncepcje Europy Środkowej jako regionu artystycznego sformułowane w literaturze naukowej.

Początki historii sztuki jako dyscypliny naukowej sięgają schyłku XVIII stulecia, jednak pierwsze profesury powołano dopiero w połowie wieku XIX w dwóch miastach środka Europy: Berlinie i Wiedniu, z którymi związana jest również geneza Kunstgeographie, a także dwóch sposobów pojmowania Europy Środkowej.

$\mathrm{Na}$ uniwersytecie w Berlinie, z którym wiążą się też początki akademickiej geografii, Gustav Friedrich von Waagen został pierwszym profesorem nadzwyczajnym historii sztuki w $1844 \mathrm{r}$., katedrę powołano w 1873 r., a osobny instytut oficjalnie otwarto w 1875 r. Zazębia się to z okresem jednoczenia państw niemieckich, zwieńczonym w $1871 \mathrm{r}$. proklamacją Cesarstwa Niemieckiego. Sprzyjało to wprzęganiu kategorii narodowych i etnicznych do rozważań na temat krajobrazu kulturowego i regionów artystycznych, przyczyniając się do skrystalizowania rozumienia Europy Środkowej, którego symbolem stała się książka Friedricha Naumanna Mitteleuropa wydana w Berlinie w 1915 r., postulująca stworzenie pola dominacji Niemiec rozciągającego się od Bałtyku po Adriatyk. Wprawdzie nie ma w niej mowy o zagadnieniach artystycznych, ale w jej programie można się dopatrzeć źródeł badania sztuki poszczególnych krain tego regionu - np. Śląska, Spiszu, Siedmiogrodu - jako obszaru niemieckiej kolonizacji artystycznej, czego szczególnie dobitne przykłady powstały w okresie III Rzeszy ${ }^{4}$.

Pierwszą profesurę historii sztuki na Uniwersytecie Wiedeńskim otrzymał w 1852 r. Rudolf Eitelberger von Edelberg, z którego inicjatywy w 1873 r. w Wiedniu odbył się też pierwszy międzynarodowy kongres historii sztuki. Dwa pokolenia młodszy wiedeński geograf, Hugo

${ }^{3}$ Nota bene Martina Schongauera i Albrechta Dürera określa Vasari jako artystów wywodzących się z Antwerpii - G. Vasari, Żywoty najsławniejszych malarzy, rzeźbiarzy $i$ architektów, t. 5, Warszawa 1986, s. 263.

${ }^{4}$ V. Roth, Die deutsche Kunst in Siebenbürgen, Berlin 1934; O. Schürer, E. Wiese, Deutsche Kunst in der Zips, Wien 1938; G. Grundmann, Deutsche Kunst im befreiten Schlesien, Breslau 1941 (2 wyd. 1944). 
Hassinger, stworzył termin Kunstgeographie ${ }^{5}$, a także jej pojęcie, głównie jako autor 15. tomu serii Österreichische Kunsttopographie, poświęconego zabytkom Wiednia ${ }^{6}$, po raz pierwszy prezentującego materiał na mapach, w których poszczególnym epokom przyporządkowano różne kolory. W klimacie wielonarodowej monarchii austro-węgierskiej wykształciło się też rozumienie Europy Środkowej, określone przez Jána Bakoša jako etatystyczne: w zasadzie utożsamiające ją z państwem rządzonym przez Habsburgów?

Po II wojnie światowej skrystalizowało się kolejne pojęcie Europy Środkowej: zakorzenione w porządku, którego symbolem stała się konferencja w Jałcie. Europą Środkową tworzyłyby kraje położone między demokratycznym Zachodem a Związkiem Radzieckim (traktowanym jako synonim Wschodu). Rodzi to jednak rozliczne problemy już w odniesieniu do drugiej połowy XX w. (Austria w sensie politycznym należy do Zachodu, ale geograficznie Wiedeń położony jest na wschód od Pragi), a tym bardziej wątpliwe staje się przeniesienie powojennego status quo na epoki wcześniejsze (by znów przywołać casus Austro-Węgier, a także podzielonych powojennych Niemiec). Za próbę wyjścia z tego impasu wolno uznać bardzo szeroką definicję, którą w 1965 r. przyjął Eberhard Hempel, uczony związany $\mathrm{z}$ drezdeńską Technische Hochschule. W podręczniku wydanym w ramach serii Pelican History of Art, poświęconym sztuce baroku w Europie Środkowej, jako jej obszar wskazał on współczesne sobie Niemcy, Austrię, Szwajcarię, Węgry, Czechosłowację i Polskę .

U schyłku lat sześćdziesiątych XX w. młode pokolenie badaczy zainicjowało systematyczną krytykę ideologicznego uwikłania niemieckiej historiografii artystycznej. Wtedy też Reiner Haussherr sformułował postulat odejścia od stosowania w Kunstgeographie klucza narodowego i etnicznego9. Przedmiotem osobnego namysłu stała się również definicja Europy Środkowej. Ważny głos padł w Budapeszcie w 1969 r., na 22 międzynarodowym

${ }^{5}$ H. Hassinger, Über Aufgaben der Städtekunde, „Dr. A. Petermanns Mitteilungen aus Justus Perthes Geographischer Anstalt" 56, 1910, s. 289-294.

${ }^{6}$ Idem, Kunsthistorischer Atlas der K. K. Reichshaupt- und Residenzstadt Wien und Verzeichnis der erhaltenswerten historischen, Kunst- und Naturdenkmale des Wiener Stadtbezirks, red. M. Dvořák, Wien 1916.

${ }^{7}$ J. Bakoš, The idea of East Central Europe as an Artistic Region and 14th-century Painting and Sculpture in Slovakia, w: Künstlerischer Austausch - Artistic Exchange. Akten des XXVIII. Internationalen Kongresses für Kunstgeschichte, Berlin, 15.-20. Juli 1992, red. T. Gaehtgens, t. 2, Berlin 1992, s. 51-64 (tu: s. 53-56).

${ }^{8}$ E. Hempel, Baroque Art and Architecture in Central Europe. Germany, Austria, Switzerland, Hungary, Czechoslovakia, Poland, Harsmonsword 1965.

${ }^{9}$ R. Haussherr, Überlegungen zum Stand der Kunstgeographie. Zwei Neuerscheinungen, „Rheinische Vierteljahrblätter” 30, 1965, s. 351-372; idem, Kunstgeographie. Aufgaben, Grenzen, Möglichkeiten, „Rheinische Vierteljahrblätter” 34, 1970, s. 158-171. 
kongresie Comité International d'Histoire de l'Art (CIHA), którego głównym wątkiem miała być refleksja nad relacją między powszechnymi procesami artystycznymi a zjawiskami regionalnymi. W jednym z referatów wprowadzających, poświęconym Europie Środkowej, Lajos Vayer uznał termin Mitteleuropa za stworzony przez geografów (na podobieństwo Mittelalter ukutego przez historyków) i przypomniał różne próby jego zdefiniowania, podkreślając jednocześnie historyczną względność wszelkich określeń ${ }^{10}$. W następnych latach - przy pewnych różnicach między badaczami z ówczesnej Polski, Czechosłowacji i Węgier - coraz częściej uwypuklano wspólne cechy regionu, zwykle ograniczanego do tych właśnie krajów, nie zawsze jednak towarzyszyła temu systematyczna refleksja metodologiczna czy choćby spójna terminologia ${ }^{11}$. Na wyróżnienie zasługuje książka Jana Białostockiego poświęcona sztuce renesansu w Europie Wschodniej wydana w roku $1976^{12}$, często następnie przywoływana w dyskusjach na temat geografii artystycznej (wraz z rok wcześniejszym artykułem tegoż badacza, podejmującym próbę zdefiniowania bałtyckiego regionu artystycznego $)^{13}$. Debata nad przedmiotem i zadaniami Kunstgeographie wciąż trwała w latach osiemdziesiątych. Wkrótce na jej dalszy kształt, podobnie jak na pojmowanie Europy Środkowej (nie tylko w historiografii artystycznej), istotnie wpłynęły przemiany polityczne, których symbolem stał się upadek muru berlińskiego.

Zwiastunem rezonansu, jaki wydarzenia te miały wywołać wśród historyków sztuki, był 27 kongres CIHA we wrześniu 1989 r. w Strasburgu, zatytułowany Sztuka i rewolucje. Jednak prawdziwie symboliczne znaczenie miał kongres następny, zorganizowany w 1992 r. w Berlinie i skupiony na zagadnieniu wymiany artystycznej. Europie Środkowej i Wschodniej poświęcono tam dwie sekcje, wydzielone chronologicznie (1250-1500 i 1500-1800 $)^{14}$. Badacze sztuki nowoczesnej i kuratorzy wystaw organizowanych w Europie i Stanach Zjednoczonych jeszcze wyraźniej formuło-

${ }^{10}$ L. Vayer, Allgemeine Entwicklung und regionale Entwicklungen in der Kunstgeschichte. Situation des Problems in „Mitteleuropa”, w: Évolution générale et développements régionaux en Histoire de l'Art. Actes du 22. Congrès International d'Histoire de l'Art, Budapest 1969, red. G. Rósza, t. 1, Budapest 1972, s. 19-29.

${ }^{11} \mathrm{~Np}$. A. Tomaszewski, Romańskie kościoły z emporami zachodnimi na obszarze Polski, Czech $i$ Węgier, Wrocław 1971, s. 8-10; A. Karłowska-Kamzowa, Malarstwo gotyckie Europy środkowowschodniej. Zagadnienie odrębności regionu, Warszawa 1982, s. 5-6, 103.

${ }_{12} \mathrm{~J}$. Białostocki, The Art of the Renaissance in Eastern Europe. Hungary-Bohemia-Poland, London 1976.

${ }^{13}$ Idem, The Baltic Area as an Artistic Region in the Sixteenth Century, „Hafnia. Copenhagen Papers in the History of Art" [4]: Comité international d'histoire de l'art. VII ${ }^{e}$ colloque international Le Pays du Nord et l'Europe. Art et Architecture au XVIe siècle, Copenhague 16 septembre 1975, 1976, s. 11-24.

${ }^{14}$ Künstlerischer Austausch, t. 2. 
wali postulat „przywrócenia” do oficjalnej narracji historii sztuki obszarów dotąd pomijanych lub traktowanych jako margines, którego granicą była żelazna kurtyna ${ }^{15}$. Historycy sztuki zaangażowali się także w powstawanie wielu inicjatyw i instytucji badawczych, nie tylko ściśle historyczno-artystycznych. Na Uniwersytecie Jana Gutenberga w Moguncji (gdzie od 1946 r. istnieje Arbeitsbereich Osteuropäische Geschichte) w 1988 r. odbyła się konferencja, która dała początek Grupie Roboczej Polskich i Niemieckich Historyków Sztuki i Konserwatorów, do dziś stanowiącej ważne forum refleksji metodologicznej ${ }^{16}$. Wśród inicjatyw wydawniczych wypada wspomnieć serię sympozjów poświęconych badaniom nad Europą Środkowo-Wschodnią publikowanych od 1996 r. przez Instytut Herdera w Marburgu, z których jeden z tomów został poświęcony historii sztuki ${ }^{17}$, a nade wszystko wydawane od 2001 r. w Nowym Jorku czasopismo "Centropa. A Journal of Central European Architecture and Related Arts". Po 1989 r. powstały nie tylko Central European University w Budapeszcie (1991) i Geisteswissenschaftliches Zentrum Geschichte und Kultur Ostmitteleuropas w Lipsku (1995, od 2003 związane z tamtejszym uniwersytetem), lecz także katedra historii sztuki wschodnioeuropejskiej (Lehrstuhl für Kunstgeschichte Osteuropas, 1993) przy Kunstgeschichtliches Seminar (obecnie Institut für Kunst- und Bildgeschichte) na Uniwersytecie Humboldtów w Berlinie. Nieocenione są zasługi kierującego kilka lat tą katedrą Adama Labudy, prowadzącego i animującego studia zarówno nad sztuką Europy Środkowej, jak i jej historiografią ${ }^{18}$. Pewien oddźwięk w badaniach znalazło też przystępowanie kolejnych

${ }^{15}$ Np. Europa, Europa, Das Jahrhundert der Avantgarde in Mittel- und Osteuropa, red. R. Stanisławski, Ch. Brockhaus, Bonn 1994 (Kunst- und Ausstellungshalle der Bundesrepublik Deutschland); Beyond Belief. Contemporary Art from East Central Europe, red. L.J. Hoptman, L. Beke, Chicago 1995 (Museum of Contemporary Art); Central European Avant-Gardes: Exchange and Transformation 1910-1930, red. T. O. Benson, Los Angeles 2002 (County Museum of Art); Monachium, 2002/2003 (Haus der Kunst), Berlin 2003 (Martin-Gropius-Bau).

${ }^{16}$ Die Etablierung und Entwicklung des Faches Kunstgeschichte in Deutschland, Polen und Mitteleuropa (anlässlich des 125-jährigen Gründungsjubiläums des ersten Lehrstuhls für Kunstgeschichte in Polen). Beiträge der 14. Tagung des Arbeitskreises deutscher und polnischer Kunsthistoriker und Denkmalpfleger in Krakau, 26.-30. September 2007/Ksztattowanie sie i rozwój historii sztuki w Niemczech, Polsce i Europie Środkowej (w 125. rocznicę utworzenia pierwszej na ziemiach polskich uniwersyteckiej katedry historii sztuki). Materiały XIV Konferencji Grupy Roboczej Polskich i Niemieckich Historyków Sztuki i Konserwatorów w Krakowie, 26-30 września 2007, red. W. Bałus, J. Wolańska, Warszawa 2010, Das gemeinsame Kulturerbe / Wspólne Dziedzictwo, 6.

${ }^{17}$ Beiträge zur Kunstgeschichte Ostmitteleuropas, red. H. Nogossek, D. Popp, Marburg 2001, Tagungen zur Ostmitteleuropa-Forschung, 13.

${ }_{18}$ A.S. Labuda, ,... eine von sinnvollen Zweckgefühlen erfüllte, herbe und großartige Kolonialkunst...”. Zum kunsthistorischen Diskurs über Ostmitteleuropa, „Zeitschrift für Kunstge- 
krajów dawnego bloku wschodniego do Unii Europejskiej, a następnie do układu z Schengen. Wokół problemu granic toczyła się dyskusja m.in. na międzynarodowych sympozjach Borders in art (Fourth Joint Conference of Polish and English Art Historians, University of East Anglia, Norwich, $1998)^{19}$ oraz The Borders in the Art History of Central Europe (Bratysława, Slovenská akadémia vied, Ústav dejín umenia, 2007) ${ }^{20}$.

Wszystkie wymienione przedsięwzięcia nie doprowadziły do przyjęcia jednolitej definicji badanego obszaru, który nazywano różnie - Europą Środkową, Środkowowschodnią lub Wschodnią ${ }^{21}$. Rozmaite były też sposoby dowartościowywania jego dorobku - przez osadzanie w kontekście sztuki Zachodu albo podkreślanie swoistości „środka Europy”. Najważniejsze jednak wydaje się to, że odniesienia do aktualnych przemian politycznych, ekonomicznych i społecznych niekiedy ściśle się splatały z recepcją nowych koncepcji metodologicznych. Kluczowe znaczenie ma tu „zwrot przestrzenny" (spatial turn) ${ }^{22}$. Jego źródeł dopatrywano się w pracach filozofów - Michela Foucaulta i Henri Lefebvre'a - z lat siedemdziesiątych $\mathrm{XX}$ w.,jednak ich rozważania na temat przestrzeni doczekały się szerszego rezonansu wśród historyków sztuki dopiero w początkach XXI w. W dyskusji tej szczególnie ważną rolę odgrywa dwóch badaczy sztuki Europy Środkowej: Thomas DaCosta Kaufmann i Piotr Piotrowski.

Pierwszy poświęcił sztuce czasów Maksymiliana II i Rudolfa II rozprawę doktorską opublikowaną w 1978 r. i w tymże roku, w recenzji wspomnianej książki J. Białostockiego z 1976 r., sformułował pionierski wówczas postulat włączenia dorobku Europy Środkowej do głównego nurtu historii sztuki ${ }^{23}$. Dziesięć lat później opracował bibliografię sztuki środkowoeuropejskiej ${ }^{24}$. Wreszcie w 1995 r. przedstawił własną wizję sztuki środka Europy: polemiczną wobec ujęcia Białostockiego, ale też wyraźnie nim zainspirowaną ${ }^{25}$. Doświadczenia te stały się dla DaCosty Kaufmanna waż-

schichte" 56, 1993, 1, s. 1-17; Die Kunsthistoriographien in Ostmitteleuropa und der nationale Diskurs, red. R. Born, A. Janatková, A. S. Labuda, Berlin 2004.

${ }^{19}$ Borders in Art. Revisiting Kunstgeographie, red. K. Murawska-Muthesius, Warszawa 2000 .

${ }^{20}$ Materiały wydane w osobnym numerze czasopisma „Ars” 40, 2007, 2.

${ }^{21}$ S. A. Mansbach, Modern Art in Eastern Europe. From the Baltic to the Balkans ca 18901939, Cambridge 1999.

${ }^{22} \mathrm{~J} .-\mathrm{M}$. Besse, Approches spatiales dans l'histoire des sciences et des arts, „L'Espace géographique" 39, 2010, 2, s. 211-224.

${ }^{23}$ T. DaCosta Kaufmann, rec.: Jan Białostocki, The Art of the Renaissance in Eastern Europe, Oxford 1976, „The Art Bulletin” 60, 1978, s. 164-169.

${ }^{24}$ Idem, Art and architecture in Central Europe 1550-1620: an annotated bibliography, Boston 1988 (2 wyd. Marburg 2003).

${ }^{25}$ Idem, Court, Cloister and the City. The Art and Culture of Central Europe 1450-1800, Chicago 1995. 
nym punktem wyjścia krytycznego namysłu nad związkami między geografią a historią, czego rezultatem jest projekt nowej geografii artystycznej ${ }^{26}$, następnie określonej jako „geohistoria sztuki” ${ }^{27}$. Polegałaby ona już nie tylko na lokowaniu zjawisk artystycznych w przestrzeni, lecz na badaniu miejsca jako czynnika wpływającego na zjawiska artystyczne, a także na sposób ich ujmowania w historiografii artystycznej.

Do tych koncepcji często odwołuje się Piotrowski, również formułujący postulaty metodologiczne na podstawie własnych doświadczeń w badaniu sztuki środkowoeuropejskiej, jednak nie nowożytnej, lecz XX w. W ostatnich kilku latach stworzył on zarys „horyzontalnej historii sztuki"28. Wstępem do niej byłaby dekonstrukcja typu narracji dominującego w dotychczasowej literaturze - określonego jako „wertykalna historia sztuki" - wedle której dzieje sztuki powszechnej są w istocie historią sztuki tworzonej w głównych ośrodkach Zachodu. Następnie ten jednorodny głos miałby zostać zastąpiony wielością narracji, których wspólną cechą byłoby zniesienie hierarchii obszarów i odrzucenie pisania z pozycji centrum na rzecz wyjścia od obszarów uznawanych za peryferyjne czy też marginalne - i tu właśnie na osobną uwagę zasługiwałby przypadek Europy Środkowej.

Namysł nad Europą Środkową stał się zatem w ostatnich latach katalizatorem nowych postulatów metodologicznych. Tymczasem trudno przesądzić, czy „horyzontalna historia sztuki” stanie się dominującą perspektywą w badaniach nad sztuką - także środkowoeuropejską. Trzeba też pamiętać, że do dziś w historiografii artystycznej pobrzmiewają, niekiedy całkiem donośnie, dawne rozumienia Europy Środkowej. Świadectwem trwałości zakorzenionego w historiografii nowożytnej skupienia na Italii i Niderlandach jako głównych centrach i źródłach inspiracji artystycznych są wciąż chętnie stosowane kategorie italianizmu i niderlandyzmu (podczas gdy brak osobnych pojęć określających oddziaływania sztuki francuskiej czy niemieckiej).Założony w 1989 r. w Oldenburgu Bundesinstitut für Kultur und Geschichte des Deutschen im östlichen Europa oczywiście nie głosi niemieckiej hegemonii kulturalnej, lecz, wspieranie kultury pamięci”,

${ }^{26}$ Idem, Toward a geography of art, Chicago 2004, zwł. s. 1-13 oraz 145, 154-186.

${ }^{27}$ Time and place. The geohistory of art, red. T. DaCosta Kaufmann, E. Pilliod, Aldershot 2005.

${ }^{28}$ Główne myśli autora, formułowane także w artykułach polsko- i angielskojęzycznych, można odnaleźć we wprowadzających rozdziałach jego książek: P.Piotrowski, Awangarda w cieniu Jałty. Sztuka w Europie Środkowo-Wschodniej 1945-1989, Poznań 2005, s. 13-36 (wyd. angielskie: In the shadow of Yalta: art and the Avant-garde in Eastern Europe, 1945-1989, London 2009; słoweńskie - Avangarda u sjeni Jalte. Umjetnost Srednjoistocne Europe u razdoblju 1945-1989, Zagreb 2011) oraz idem, Agorafilia. Sztuka i demokracja w postkomunistycznej Europie, Poznań 2010, s. 15-55. 
ale skupiając się na wkładzie Niemców w spuściznę krajów środkowoi wschodnioeuropejskich, bierze pod uwage - jak głosi program badań naukowych na lata 2012-2014 ogłoszony na stronie internetowej - także polityczną i społeczną aktualność realizowanych projektów ${ }^{29}$. Wreszcie sentyment dla monarchii austro-węgierskiej pozostaje nieobcy badaczom, zwłaszcza wywodzącym się z jej dawnego obszaru, którzy budują wokół Austrii pojęcie Europy Środkowej nie tylko na badaniach nad sztuką okresu $1867-1918^{30}$, lecz także nowożytną i średniowieczną ${ }^{31}$. Etatystyczne, czy raczej dynastyczne rozumienie Mitteleuropa ma zresztą, oprócz habsburskiej, także odmianę jagiellońską, czego najnowszym świadectwem jest wystawa Europa Jagellonica 1386-1572. Kultura i sztuka Europy Środkowej za czasów panowania dynastii Jagiellonów (Kutná Hora, Galerie Středočeského kraje; 2012; Warszawa, Muzeum Narodowe i Zamek Królewski, 2012/2013; Poczdam, Haus der Brandenburgisch-Preußischen Geschichte, 2013). Nade wszystko zaś, definicji Europy Środkowej wciąż poświęcane są osobne publikacje, jednak ich tytułom często towarzyszą znaki zapytania ${ }^{32}$.

${ }^{29}\langle$ http://www.bkge.de/pl/59606.html〉 (dostęp: 4 VII 2012).

${ }^{30}$ Np. Á. Moravánszky, Die Architektur der Donaumonarchie 1867 bis 1918, Berlin 1988 (wyd. węgierskie: Épitészet az Osztrák-Magyar Monarchiában: 1867-1918, Budapest 1988).

${ }^{31}$ Jest to widoczne np. w tomie Internationale Gotik in Mitteleuropa, red. G. Pochat, B. Wagner, Graz 1991, Kunsthistorisches Jahrbuch Graz, 24.

${ }^{32} \mathrm{M}$. Fabiański, How can an artistic region be defined? The case of early-modern Central Europe, w: Borders in Art, s. 35-42; M. Dmitrieva-Einhorn, Gibt es eine Kunstlandschaft Ostmitteleuropa? Forschungsprobleme der Kunstgeographie, w: Die Kunsthistoriographien in Ostmitteleuropa, s. 121-137; T. DaCosta Kaufmann, (Ost-)Mitteleuropa als Kunstgeschichtsregion?, Leipzig 2006; P. Piotrowski, Czy (wciaż) istnieje Europa Środkowa i czy (jeszcze) ma coś do powiedzenia / Does Central Europe (still) Exist, and Does it (still) Have Something Important to Say?, w: Mediations Biennale, Poznań 2008, s. 28-55, idem, How to Write a History of Central-East European Art?, ,Third Text” 23, 2009, s. 5-14. 